The Bio-Origins Series 


\section{THE BIO-ORIGINS SERIES}

Genesis on Planet Earth: The Search for Life's Beginning, 2d edition, William Day, 1984

Origins of Sex: Three Billion Years of Genetic Recombination, Lynn Margulis and Dorion Sagan, 1986

Forthcoming

Concepts of Symbiogenesis: A Historical and Critical Study of the Research of Russian Botanists, Liya N. Khakhina, edited by Lynn Margulis and Mark McMenamin 
Harold J. Morowitz

\section{BEGINNINGS OF}

\section{CELLULAR LIFE}

METAB OLISM

RECAPITULATES

BIOGENESIS

Yale University Press New Haven and London 
Published with assistance from the foundation established in memory of William McKean Brown.

Excerpts in chapter 3 are reprinted with kind permission of Princeton University Press, from Earth's Earliest Biosphere, edited by J. William Schopf, copyright 1983 by Princeton University Press; Karl Popper, from The Logic of Scientific Discovery, originally published in German in 1934, with an American edition in 1959; and Van Nostrand Reinhold, from "Stromatolites," Encyclopedia of Paleontology, R. W. Fairbridge, 1977, pp. 770-71.

Copyright (C) 1992 by Yale University.

All rights reserved. This book may not be reproduced, in whole or in part, including illustrations, in any form (beyond that copying permitted by Sections 107 and 108 of the U.S. Copyright Law and except by reviewers for the public press), without written permission from the publishers.

Set in Times Roman type by Asco Trade Typesetting Lid., Hong Kong. Printed in the United States of America by Vail-Ballou Press, Binghamton, New York.

\section{Library of Congress Cataloging-in-Publication Data}

Morowitz, Harold J.

Beginnings of cellular life : metabolism recapitulates biogenesis

Harold J. Morowitz.

p. cm.-(Bio-origins series)

Includes bibliographical references ( $p . \quad$ ) and index. ISBN 0-300-05483-1 (alk. paper)

1. Life-Origin. I. Title. II. Series. QH325.M778 1992

$577-\mathrm{dc} 20$

The paper in this book meets the guidelines for permanence and durability of the Committee on Production Guidelines for Book Longevity of the Council on Library Resources. 
I believe a leaf of grass is no less than the journey-work of the stars.

Leaves of Grass

Walt Whitman 
This page intentionally left blank 